\title{
Appraising Commercial Expenditure Efficiency of General Medical Education and Residency Programmes in Nigeria
}

\author{
Christopher Enyioma Alozie ${ }^{1}\left(\mathbb{C}\right.$, Abel O. Ideh $^{2}(10$ \\ ${ }^{1}$ Tansian University, Umunya, Nigeria \\ ${ }^{2}$ Delta State University, Abraka, Nigeria \\ Email: krisnedum2@gmail.com
}

How to cite this paper: Alozie, C.E. and Ideh, A.O. (2020) Appraising Commercial Expenditure Efficiency of General Medical Education and Residency Programmes in Nigeria. Journal of Mathematical Finance, 10, 345-375.

https://doi.org/10.4236/jmf.2020.102021

Received: March 3, 2020

Accepted: May 22, 2020

Published: May 25, 2020

Copyright $\odot 2020$ by author(s) and Scientific Research Publishing Inc. This work is licensed under the Creative Commons Attribution International License (CC BY 4.0).

http://creativecommons.org/licenses/by/4.0/

\section{(c) (i) Open Access}

\begin{abstract}
Purpose: The purpose of the research is to establish the standard period taken in full recovery of cost outlays, rate of returns for general physicians and marginal returns to consultants, and appropriate profitability indices. Mixed ex-post "facto" data and primary data-sets pertaining medical education expenditure across levels and lifecycle career earnings of Nigerian physicians in public service were employed. The longitudinal secondary and primary data-set were obtained from cohorts of physicians that participated in the two stages of medical education, published programmes charges posted in brochures of some public universities' medical schools and gazette consolidated medical salaries scheme of scale for medical workers in the public service. Method of Analysis: Break-even analysis was applied to determine minimum number of years required to fully invested capital; "elaborate (full cash flows) discounting" with internal rate of return method was used for calculation of the private and marginal rate of returns. Then, profitability ratio approach was applied to determine the level of viability of medical education across levels. Cost construction indicates that about N30 million and N69.5 million are committed as investments on general medical education and residency training of the licensed general physicians and consultant-physicians respectively. The lifecycle career earnings estimates of the general practice physicians and consultant-physicians employed in the public service worth N356 million and 814 million. Results: The break-even period for full recovery of investments in general practice physicians is 5.25 around the thirteenth years of medical education and 6.33 years for residency-trained consultants, occurring in the 21 st period of this layer of vocational training respectively. Individual rate of returns on investments in general medical education of average licensed general physicians is 32 percent and 32 percent marginal rate of returns to additional investment expenditures on residency training (earn-
\end{abstract}


ings premium of consultant-physicians). This combined rate of returns of consultant-doctors (general medicine plus residency training) is 64 percent. Net present value of cash-flows of the average general physician and consultant-doctors in Nigeria is worth N326 million and N744 million respectively. Whilst the profitability index derived from the present value of net cash-flows is 1.32 for general physicians and 1.69 for the specialist. Conclusion: The paper concludes that investments to medical education in Nigeria are worth-while; but more rewarding for residency training. Timing of education (age-range when doctors get certified) influences the earnings and rate returns to investments and value of one's intellectual capital and net-worth (statistical financial value of life). Contribution to Knowledge: The results of assessment of individual's expenditure efficiency in medical/higher education confirm that investment in medical education is worthwhile. The findings enhance rational decision for individuals, private sector and government organizations respectively and veritable information for policy formulation. Originality: This research is an exploratory assessment of individual participants' spending efficiency in medical education in Nigeria and other developing country establishes tentative pay-back period of such investments, unit rates of returns across levels and profitability indices.

\section{Keywords}

Medical Education, Up-Front Capital Investments, Career Earnings, Rate of Returns, Time Management Dimension in Higher Education, Nigeria

\section{Introduction}

The paper considered medical education as units of human capital investment asset that generates cash-flows after licensure and form the basis of assessing the feasibility, viability of medical education in the economy. Whilst attainment of higher education enhances individual's chances to secure employment, offering international labour mobility for physicians; higher education paves way to attaining leadership and self-actualization [1]. Individual's investment in medical education is necessary in health manpower development, increased productivity and economic growth. Contextually, it is expedient to perform cash in-flows/out-flows analysis in ascertaining commercial feasibility and viability of human capital investments in physicians' education.

Medical education at undergraduate and residency is capital intensive with long gestation period to generate cash-flows. Consequently, physicians-in-training lacking adequate funds to finance medical education particularly those without free scholarship often resort to borrow funds from commercial banks at market lending rates to complete their programmes. Government organizations on their part also source fund for providing relevant intervention projects/facilities in medical education from development finance institutions. These education loans attract rates of interests ranging from 24 to 30 percent in commercial banks. Nigeria's monetary authority in fixed monetary policy lending rates (MPLR) is also trea- 
sury bills (TBs) interest rate in the range of 17.5 to 20 percent. This represents the effective discount rates in the Nigerian economy. In the same vein, the international development institutions charge five percent concessionary interest rates on credit facilities extended to public entities [2] [3] and adopted as interest rate for social capital projects in the context of this study.

Investment appraisal in this research involves compilation of individual's private and public investment expenditures, breakeven analysis of cash-flows with determination of pay-back period of full recovery of total cost outlay. Thus, the paper appraises commercial feasibility, viability and spending efficiency of investments in intellectual capital of medical doctors. Unit costs and earnings data were generated from sample representatives of physicians' cohorts of trained within the last two decades (2003-2018). The break-even (pay-back) period analysis, net present value-internal rate of return linked profitability indexing, individual rate and marginal rate of return on earnings premium of consultant physician over their general practice physician counterparts were performed. Through this process, the paper establishes private rate of return and marginal rate of return (premium) of residency training over the baseline medical training.

Construction of costs show that about N30 million and N69.5 million were committed as unit investments on general medical education and residency training of the licensed general physicians and consultant-physicians respectively. Lifecycle career earnings estimates of general practice physicians and consultant-physicians employed in the public service worth N356 million and 814 million. Flowing from these costs and earnings profiles, break-even analysis was applied to determine minimum number of years required to fully invested capital; "elaborate (full cash flows) discounting" with internal rate of return method was used for calculation of the private and marginal rate of returns. Lastly, the profitability ratio approach was applied to determine the level of viability of medical education.

Result of break-even period for full recovery of investments in general practice physicians is 5.25 (around the thirteenth years from commencing of medical education) and $61 / 3$ years for residency-trained consultants (which occurs in the twenty-first period of vocational training) respectively. Individual rate of returns on investments in general medical education of licensed general physicians is 32 percent and 32 percent as marginal rate of returns to additional investment expenditures on residency training (earnings premium of consultant-physicians). The combined rate of returns of the consultants for general medicine plus residency training) is estimated is on the aggregate, about 64 percent. Net present value of cash-flows of general physician and consultant-doctors in Nigeria is worth N326 million and N744 million respectively. Profitability index derived from present value of general physicians and consultant-physician net cash-flows. These represent inverted value of the discounting factor for $(r)=1.0 / 1.0 / 1.32$ equals to 1.32 and $1.0 / 1.0 / 1.64$ equals to 1.32 with respect to N326 million and N744 million in 35 years respectively. 
Participants in medical education that collected medical education loans bear huge debt burden that repayment linger almost throughout their careers. Lack of information pertaining total upfront expenditure outlays for medical education, projection of lifecycle career earnings and pay-back (break-even) period apparently compelled many trainee-physicians in incurring huge medical education loans with prolonged repayments. It was argued in Chen (2012) [3] that the affected individuals repay the loans for several years after graduation; and Roth [4] corroborated the fact that physicians accumulate debt worth US $\$ 156,000$ or equivalent of $\mathrm{N} 30$ million on the average. The situation in Nigeria is even worse because there study loan scheme is not quite effective. In effect, lack of information on spending efficiency in medical education in Nigeria makes it difficult for the participants in medical education and health policy-makers to capture reliable estimates of cost of training physicians in fiscal budgeting. Healey and Gunby [5] explained that availability of information on expenditures on educating clinicians, labour wages and returns on investment to medical education in the UK's is critical to demand for physicians. Participants in medical education or sponsors-financiers as prudent investors expected to utilize funds invested in medical education to purchase government bond which is tax-free is investment securities issued by government. Treasury bills interest rate which is fixed by Central Bank of Nigeria represents effective discounting rate in the economy [3] [6]. This risk-free rate of return is used as a benchmark for rate of return in the economy. Based on these premises, this paper adopted seven years and 14 years as the minimum pay-back periods for each of the two tiers of medical training. Then, it applied $18 \%$ as discounting factor and minimum acceptance criterion for private rate of returns; 15 percent as idealized minimum marginal return on residency training over baseline (first tier) medical education and profitability ratio of 1.2 as parameter for test statistic for viability.

The production and availability of suitable mix of high level medical workforce is essential in health service delivery but expensive. But there is dearth of data/information on cost, benefit and returns on investment in developing countries including Nigeria [7]. Lack of data originates partly from inadequate funding of medical schools for medical research activities; insufficient institutional spending and financial grants to undergraduate medical students and residents. Budgetary allocation and fund disbursement to health sector in Nigeria seem insufficient and Osotimehin [8] affirmed that paucity of reliable information relating to public expenditures of both undergraduate, medical residency programmes in Nigeria. This result in poor remunerations of physicians in the public health services coupled with inadequate facilities and incessant strike actions.

Break-even period analysis with relevant years of full recovery of capital, rate of returns, marginal rate of return and net present value-linked profitability index are mathematical finance method employed to measure feasibility of investments in medical education in this paper. These four species of investment efficiency measurement are often used in higher education to gauge and select 
projects that satisfy minimum acceptable criterion in comparison to alternative opportunities or otherwise. Furthermore, marginal rate of private return is used in evaluation incremental financial gains accruing from additional investments in medical residency programmes above general medical education. A high rate of private financial returns, fiscal and socio-economic returns act as strong inducement to individuals, sponsors and government to invest in tertiary education beyond free/compulsory basic education [9] ((OECD), 2013). A low rate of financial returns, may act as disincentive to investing in education and training. Although Nigerian government offers free and compulsory education up to secondary school level education). This does not guarantee adequate annual turnout of newly qualified physicians in the nation.

A plethora of empirical studies have assessed private investment efficiency on medical education in many countries but there is dearth of studies on returns on investments to medical education in Nigeria. This research is therefore motivated by the need to determine break-even period of full recovery of capital investments, rates of returns, marginal rate of return and profitability indicators of investments in medical education in Nigeria. The rendition of empirically established level of viability and private spending efficiency of medical education are necessary for career and investment decision of individual participants in medical training. Specifically, the information is critical factors for investor's decision in microenterprise or entrepreneurship and health planning. Furthermore, several prior studies have relied on Mincer's earnings method, claimed to establish the returns to education based on the average additional year of schooling. This can be considered appropriate (to some extent) in national planning but it does not appear to have produced reliable estimates of private returns to higher education [10]. The present study bridge the existing gap in human capital measurement modelling by utilizing unit CBA method and provides reliable rate of returns to medical education that which yields robust rate(s) of returns greater than the Mincer's method. Deliverables from this research serves as veritable data to guide public health planers in policy formulation; governments, institutions, household units and participants in medical training in financing medical education in Nigeria.

The main objective of the study is to assessment of the viability of investments in medical education in Nigeria. Specific objectives are to: establish pay-back period of Nigeria's domestically trained and practising physicians to recoup investment medical education during the review period. To determine individual rate of return on investments in medical education of Nigeria's domestically trained and licensed practising general and consultant physicians. It will also determine marginal rate of return on additional expenditure for residency associated with earnings premium of consultant-physicians above general practice physicians for a-35 lifecycle years of service. Finally, the paper derives profitability index of general medical education and residency qualified consultant physicians respectively. 
The assessment of feasibility and commercial viability of investments in medical education in Nigeria is significant in several dimensions. First, there is lack of data sets and information pertaining total costs of academic education and professional training of physicians in Nigeria to guide prospective trainees in career decisions. It also provides assessment of private spending efficiency on investment in the education and professional training of the medical doctors in comparison with alternative investment assets and social returns from on other public capital programmes in Nigeria's economy.

The scope of this paper are to determine break-even (pay-back) period, individual rate of returns of the baseline medical education; marginal rate of returns to additional investments to residency training programmes and profitability indices of the Nigerian produced physicians in past two decades. The cohorts of graduate in medicine (medical officers) are those that successfully completed their MB.BS medical training, and secured license and registration with the Medical and Dental Council of Nigeria. These physicians are those that have completed compulsory one-year internship, inducted and licensed as medical doctors and have duly completed the national youth service scheme not later than 2018. The paper essentially estimates total costs and earnings of physicians' 7-years Bachelor of Medicine and Bachelor of Surgery (MBBS) award on one side; total costs and earnings of another 6-years' professionally certified medical experts that attained fellowship award of the Nigerian post-Graduate Medical College. Therefore, estimation of costs of investment in education exclude costs related to preparatory, primary and secondary education on one hand. The streams of cash-inflows from earnings (benefits) is restricted to the post-qualification start-up salaries of physicians from 2018 for 35 years (subject to the year of qualification), with annual incremental rates applied in projecting the pay-back period and total life-cycle income-earning till the age of 60 or 70 in the case of consultant physicians.

The remainder of this paper includes the review of literature in section two; methodology and analysis results in sections three and four with the summary and conclusions in section five.

\section{Review of Literature}

\subsection{Conceptual Literature}

Human capital concept in economics has been consistently used in describing both the time, financial resources committed on acquisition of education [11] [1]. Other skill development activities and healthcare raise productivity in the economy, especially where such factors are increased [12]. Lawanson further argued that education and human health services are two closely related to human capital working together to make individual more productive. Human capital is commonly taken to include peoples' knowledge and skills acquired partly through education, but can also include their strength and vitality, which are dependent on their health and nutrition [13]. Arrow argues that whilst high in- 
comes may be conducive to health, it cannot be directly purchased like material goods and services. The provision of human medical care can only achieved through availability of physicians is anchored medical education are often subsidized by the state [13]. For this reason, education is compulsory for certain minimum length of time in many countries. Investment in human capital is embedded with the principle of allocative efficiency in educational spending [13]. Maani [10] opined that the concept of allocative efficiency and viability were drawn the economics of production, economies of scales and optimal utilization of scarce resources within educational sector [14]; and more specifically on medical education and health care delivery system [4].

Human capital is defined as expenditures incurred in the education, training, human health-care systems and medical services are investments in human capital [4] [7]. Resources committed into human capital development are not simply costs, but they are worth much more than that, but investments with valuable returns that can be calculated and measurable [1]. Health economics is the branch of economics concerned with the formal analysis of costs, physicians' career earnings, returns, and management of health services and consequences of population on the economy [13]. Roth [4] argued that expenditures and activities on education and medical care contribute to improve health conditions of the society, raise persons income and or earnings, and also add to a person's appreciation in knowledge, expertise, and literacy over a life-time.

Investment in education is considered similar to other types of short, medium and long term capital investment in financial assets, acquisition of physical assets or projects. These investments in education involve initial expenditure outlays with or without immediate cash-inflow streams, with expectation of generation revenues or cost-savings and other benefits in the future. Roth submitted that expenditure on health systems and medical services form part of investment in human development.

Fiamholtz [15] considered funds committed as recurrent expenditures in accounting records of private and public organizations as components of human capital investments such expense items are not properly treated or capitalized as assets. Fiamholtz argue that organizations merely charged as recurrent expenses used in reducing the income of organizations as opposed to its recognition as investment expenditure, which produce current and future benefits to corporate entities. Fiamhlotz explained further that the net benefits are just the only aspect of recurrent spending on human capital investment and benefits being reflected in corporate financial reporting. Similarly, expenditures on education, training and related costs are treated recurrent expenditure in public sector accounting/health accounts [7] [14]. Becker [1] and Psacharoupolus [14] explained that people who attained higher education receive higher salary than those with lower or non-formal training. Becker [1] posited that, in certain cases, earnings of people who attained tertiary education vary from profession to profession.

From the labour economics and market perspectives, investments in human 
capital is concerned with education and training of people and workforce that could sufficiently satisfy the mix of workers needed in different facets of the nation's economy. Labour economics seeks to create proper understanding of the functioning and dynamics of the markets and the wage for labour linkages. Labour markets functions through the interaction of workers and employers. Labour economics looks at the suppliers of labour services (workers) and the hirers of labour services (employers), and attempts to understand the resulting pattern of wages, employment, and income. In labour economics, labour is a measure of the work done by human beings using the prices of labour as one of the core determinants. It is conventionally contrasted with such other factors of production as land and capital.

Mincer [16] provides a review of large number of studies on human capital formation through training and learning on-the-job. One of the major contributions of human capital theory was its explanation of how much firms choose to invest in on-the-job training and who pays for it under different market conditions [11] [17] (Mincer 1977). Mincer also reported that the considerable empirical results on these issues from both early and more recent studies. His work converges with the results reported in Murphy and Welch [18] indicates that market demand for human capital increases with changing technology.

Labour market studies relate wage rates of labour prices of people that attained post-basic school education with the demand for skilled labour and productivity. This leads to the conceptual framework and signaling theory in labour economics as we shall see later under in sub-section 2.3.3. In essence, the concept of acquisition of tertiary education and skills holds that, the higher education persons acquire, the higher the salary income they receive. Individual's earnings increase with age, attaining its peak at some point but decrease upon reaching but in the case of doctors may peak at the age of about 60 in Nigeria; extending up to the age 70 years consultants as in other countries.

Earning differential between with college degrees and persons without, that is, by not working for four years, university student incurs an indirect (opportunity) cost in terms of forgone earnings equal to what secondary school graduates of the same age are earning in the labour market. This concept also relates the difference between earnings of master's degree holder above bachelor's degree holders but more often, the earnings of doctorate degrees above master's degrees; general practice physicians and consultant-physicians etcetera. In the same vein, university student incurs a direct cost (private costs) representing any tuition and incidental expenses he or she is paying for his or her studies. After graduation at around the age of 22 , the university graduate will start earning more than secondary school graduates of the same age are earning in the labour market, and the earnings advantage of the university graduate will continue over a lifetime. Furthermore, the concept of "wage premium for university graduates over secondary school graduates; 2) human or intellectual capital, the labour market and corporate productivity or performance"; 3 ) entrepreneurial human 
capital model, which sees medical education and the investment in physicians' education as enterprise capital; the economic and commercial viability perspective of investment expenditure in education.

\subsection{Theoretical Framework}

\subsubsection{Human Capital Investment, Earnings and Commercial Efficiency Evaluation}

Human capital investment and human development theory is rooted in macroeconomics, economics of development and microeconomic (profitability and economic growth) theory. Becker [11] explains that there are three different kinds of human capital investments. These include investment in formal education or schooling, vocational training like computer training courses and expenditures on medical care. Keeping with the tenets of human capital theory, the capital concept as traditionally defined; consider expenditures on education, training, medical care etcetera as investments in human capital. Education and training expenditure are not simply costs but investments with valuable returns that can be quantified and measured. Becker [11] emphasized socio-economic significance of human capital theory; noting that the most valuable of all forms of capital is the investment in human being and distinguished general-purpose type of human capital, institution's specific and other forms of specialized professional expertise. Romele and Purgailis (2013) [19] considered education and professional training in medicine, engineering and piloting as specialized human capital because these professional practice cannot be substituted, regardless of the mode of utilization.

Upfront investments, career earnings and returns to medical education are all anchored on human capital theory and efficiency hypothesis in allocation of scarce investible funds amidst competitive selection of investment options [14] [20]. Human capital theory suggest that education and training raises productivity of employees, but more specifically the skilled workers by imparting useful knowledge and skills, hence raising workers' future income and lifetime earnings [11] [15] [16] provided pertinent explanations linking investment and professional training of the skilled workers with improved remunerations. Furthermore, human capital investment to education is anchored on microeconomic theory (private investing decision) where commercial feasibility and viability is the key measure of success and decision-making criterion. The principle of macroeconomic theory (public subvention expenditure) in the case of production and delivery of public services in sufficient volume and affordable pricing is key measure of success and a decision criterion. The principle of allocative efficiency and prioritization of use of scarce resources are key factors influencing selection of investment option(s). This perception reinforce the necessity to ascertain efficiency in allocation of educational spending which flows from economics of production and anchors optimal utilization of scarce resources theorem, specifically, within medical education. 


\subsubsection{Signalling Theory, Earnings Premium of Residency and General Medical Education}

Spencer (1973) [21] originally developed the job market signalling model and it states that that potential employee sends signal about the ability level to the employer by acquiring education credentials. Swati (2016) [22] notes that whilst human capital theory claims that education raises wages of employees; the signalling theory modifies the claims that education raise wages because education level is simply a signal of the workers ability unobserved by the employer. The signaling theory in economics is the labour market model being applied in the analysis employment contract which credibly explains the perception of information characteristics of potential employees' ability level to the principal or contracting authority [22]. Murphy and Welch [18] contended that wage premium for college graduates and earnings premium in the medicine is at the heart of assessment of profitability of investments in higher education. Murphy and Welch further explained that internal rate of return method is frequently employed in estimating rate of returns on educational investment. However, marginal benefit relates earnings differential from higher university degree education over high school diploma is normally represented by higher earnings (premium) received over a lifetime.

The additional earnings and expenditures are core variables utilized in assessment of profitability, representing the justification of acquisition of higher level of education over lower levels by discounting future earnings to present values. Participation in residency training and other specialized training programmes is a common phenomenon of medical education. Normally, it involves substantial additional educational expenditures, time and intellectual rigour and attracts exceptionally higher earnings, being referred to as earnings premium. Earnings differential and marginal return on additional investment in education act as screening indicator used in assessing private financial gains and incremental profit under signalling theory. The traditional theory of supply and demand implies that the more skilled individuals there are; the higher education; higher the earnings premium and rate of return.

\subsection{Technical Specifications of Medical Education}

There are two broad dimensions of the technical specifications of medical education in different countries and economic jurisdictions globally that impact on supply, density and skill-mix of medical doctors. These are broadly subdivided into the basic medical training and out-turn of general practice physicians and residency programmes. Residency training is the process where the consultant/highly skilled medical experts are produced. This mixture of skills from the two layers of medical education is the source producing general physicians and specialists which is necessary condition for health systems development and sustenance of effective health care delivery.

\subsubsection{Baseline (Undergraduate-MBBS) Medical Education Programme}

The basic general medical training in Nigeria and in some other countries runs 
for minimum of seven years. Nigerian medical students exercise the option to acquire training either in Nigerian medical school or in foreign universities. However, for those that obtained medical training in foreign medical schools, it is mandatory for such foreign Nigerian physicians to undergo medical registration course and examination of the MDCN before they can receive the license to practice in Nigeria. The medical regulatory body requires that graduates of the foreign medical schools must attend a joint four month remedial course at a Nigerian teaching hospital, after which he or she will be assessed by MDCN for eligibility to practice medicine in Nigeria [23] (Olukadiya, 2016).

\subsubsection{Residency Training Programme}

Residency training programme is the post-graduate medical education in which the MBBS holders pursue additional specialist course which leads to professional fellowship examination of the Nigeria's National College of Physicians (FNCP), West African College or Royal College of Physicians/Surgeons (UK) equivalence. This programme runs for minimum of five or 6 years and it is substantial supported by government, with residents paid some moderated and graduated monthly residency stipends as salary throughout the prograame. Prospective medical officers are enrolled into the scheme through series of highly competitive selection examination to fill the limited slots in residency programme of the medical schools duly approved to run the training in designated teaching hospitals. This means that to become a specialist doctor, the participants are likely to commit between 12 and 17 years of training, counting from your first year in the university.

\subsection{Review of Empirical Studies}

Engelage and Hadjar [24] studied earnings differentials between the Masters' degree and Ph.D degree holders for Switzerland. They use survey of Masters and Ph.D graduates from 1983 to 2001. In their career earnings regressions the authors control for period effects, sex, interaction terms between gender and Ph.D graduation, and age. The paper found positive returns across all field of study in two years after graduation. This positive return rages from 11 percent in the humanities/social sciences to 35 percent for engineering. Mertens, Röbken and Merteins [25] examined differences in salaries and working time of doctorate holders in comparison to graduates with a master or equivalent degree (in Germany, first university degree is called a "diploma" or "state examination" depending on the field of study. The diploma degree and the state examination are equivalent to a Master's degree as they typically require a 5 year full time study programme. The authors noted that it was only after the implementation of the so-called Bologna reform in 1998, that the universities in Germany introduce the Bachelor and Master's degrees programmes and awards; distinguishing between different fields of study. Data used in the empirical analysis were drawn from micro-census (2006) of the German Federal Statistical Office. Results indicate that doctorate holders tend to work longer hours than graduates with a master 
degree, especially doctorate holders in economics, law and social sciences. A doctoral degree has a positive effect on the income-situation in nearly all tested fields of study. Graduates from the field of economics and law in particular earn comparatively high incomes.

Borad [26] determined net present value of medical education and rate of returns to costs over a lifetime. Results show that net present values of each of the 25 medical specialties across 50 states indicate that the highest NPV across each specialty reflected the state most desirable for an aspiring Anesthesiologist to practice in South Dakota with highest net present value of $\$ 4,027,114.49$, on investment relative to other locations. Within New Jersey, a career an Orthopedist produced NPV of $\$ 3,089,815.27$ which is the greatest relative to other specialties in the state. The three other top specialties that produced the greatest overall value are Orthopedics, Urology, and Cardiology with average NPVs of $\$ 3,982,179.42, \$ 3,560,190.71$, respectively. And, the three best states to practice medicine by virtue of their NPVs are Mississippi, South Dakota, and Alabama are $\$ 3,080,384.71 ; \$ 2,958,713.73 ; \$ 2,948,438.89)$ in that sequence. The paper concluded that a career in medicine remains a desirable investment for college graduates; even the lowest earning physician specialty (Infectious Disease) can expect to enjoy a net present value of over $\$ 720,000$ on an investment on medical education.

van der Steerg, van der Wiel and Wouterse [27] assessed marginal returns to a $\mathrm{Ph} . \mathrm{D}$ (degree) education in the Netherlands, based on career earnings differences between Masters and Ph.D graduates. The authors applied the average annual accounting rate of return (AAA); internal rate of return techniques alongside Mincer's earnings function methodology to derive the variations. Results show that the first year after Ph.D graduation, Ph.D earn less than Masters; but the initial investments is compensated by higher earnings in later years. Average annual return to Ph.D over the entire career is $6 \%$ with IRR of $9 \%$. The extrapolated lifetime returns to Ph.D in Netherlands seem relatively low compared to the findings from Switzerland and Germany that reported returns in the range of $10 \%-35 \%$. The paper observed higher individual returns for external Ph.D scholars within earlier years of graduation offer an indication that external experience can improve labour market of Ph.D holders.

Roth [4] carried-out benefit-to-cost analysis and determined private internal rate of returns and net present values (NPV) of those investments across a range of medical specialities at the University College, Los Angeles at Berkeley, (UCLA). Roth applied cost construction methodology with absorption of cost of teaching, residency enrolment, faculty and residents' salaries and benefits; operating costs and the associated administrative charges. The paper calculated these values under two different assumptions and used two discount rates in the computation of NPV. CBA analysis covered radiology, oncology, orthopaedic surgery, and rheumatology and paediatrics specialties. Result of indicate that average cost of residency training was estimated at US\$75,070 per year (or its naira 
cross-rate in 2012) for each carrying student. This amounts to total fee of US $\$ 300,280$ for 4-years course and US\$375350 for the 5-years course respectively. This cost-outlay is less than the estimated replacement value of teaching and clinical services provided residents, worth US\$103,436 per resident fellow per year. The paper concludes that investment in medical education in USA is viable and feasible. Chisholm-Burns, Gatwood, Spivey and Dickey [28] performed a break-even income analysis of pharmacy graduates compared to high school and college graduates to project the net cumulative income break-even point between practicing pharmacists and those who enter the workforce directly after high school graduation or after obtaining a bachelor's degree. The authors adopted markov modeling and break-even analyses were conducted. For estimated costs of education in calculating net early career earnings of high school graduates, bachelor's degree holders, pharmacists without residency training, and pharmacists with residency training. Results indicate that over the first 10 years of a pharmacist's career, they accumulate net earnings of $\$ 716,345$ to $\$ 1,064,840$, depending on cost of obtaining the Pharm. D degree and career path followed. In the break-even analysis, all pharmacy career tracks surpassed net cumulative earnings of high school graduates by age 33 and bachelor's degree holders by age 34 . Regardless of the chosen pharmacy career track and the typical cost of obtaining a Pharm-D degree, the model under study assumptions demonstrates that pharmacy education has a positive financial return on investment, with a projected break-even point of less than 10 years upon career entry.

These empirical studies provided useful guides to studies on estimation of costs, earnings and measurement of rate of returns to medical education and training conducted other countries but did not report Nigerian experience at all. The reviewed studies have demonstrated that investment in medical education is necessary in health policy formulation, planning and financing of health care programmes and for the operations and management of universities medical schools/teaching hospital complexes in Nigeria as in other countries. However, none of the reviewed studies carried out empirical study on cost-benefit analysis of investments in education and medical education in Nigeria, therefore, they did not render any report on the rates of returns to on investment to medical education in Nigeria. Similarly, majority of the reviewed studies did not employ the unit cost benefit analysis approach with the elaborate (full cash-flows discounting) methodology in assessing the economic viability of investments in medical education either in microeconomic, macroeconomics and economics of development context.

\section{Methodology}

The study constructed aggregate investment outlay(s) of individual participants in medical education and estimates lifecycle career earnings estimate(s) of sampled representative from cohorts of medical doctors that enrolled and graduated 
within last two decade. Thereafter, the paper calculates break-even (pay-back) period for full recovery of total upfront investment expenditure incurred by each graduated doctor (unit cost); the private rate of returns from streams of earnings inflows; marginal rate of return on earnings premium of consultants over the GPs and profitability indices of the two categories of medical practitioners. With these measurements, the study evaluates investment efficiency of medical education in Nigeria.

The paper employs a mixture of ex-post "facto" analysis, augmented with survey method involving direct interactive contact with participants in fact-gathering process of data used in analyses. The procedures were facilitated through extraction of expenditures for relevant medical training and earnings data. However, the study relies on secondary data from government sources pertaining expenditures in medical education, estimates of physicians' annual and aggregate life-cycle career earnings in measuring the recovery period, private returns, marginal returns and profitability index in comparison with idealized rates of returns of alternative investments.

\subsection{Materials and Methods of Collection}

Primary and secondary data were generated from primary and secondary sources are utilised in the analysis and measuring of profitability of medical education. Primary data were obtained through survey instruments and these were assembled primarily to supported array of secondary datasets. Data expenditures on medical education, earnings of medical practitioners were obtained from doctors that trained in public medical schools and earnings of the physicians on full time employment of the federal public health services and the public universities teaching hospitals that offered both undergraduate medical and post graduate residency programmes. General physicians and consultant physicians drawn from different cohorts of doctors that trained in Nigerian public universities' medical schools constituted representatives of research population. Convenience sampling method was followed in administration of survey instruments. To ensure regional spread and balanced representation in both the unit total expenditures of medical education and physicians' life-cycle career earnings in Nigeria, the study collected primary data from the minimum of sixty respondents (40 males and 20 females). These participants were drawn from different public medical schools and doctors serving in government hospital and public service; bringing total respondents in the survey to 300 from different geo-political locations.

Primary data were sourced directly from participants, particularly medical trainees that matriculated in 2003-2008 academic session and duly completed 7-year medical training inclusive of internship in Nigeria. Thereafter, secure employment in public sector and or proprietary hospital service. Similarly, data-sets from participants completed and successfully graduated from a further 6-year residency training in Nigeria were collected and used. Data sets relate to 
expenditures on medical education, earnings of medical practitioners were obtained from public universities' medical schools/teaching hospitals that consistently run undergraduate and post-graduate residency programmes. Primary data on individual's up-keep expenses, incidental expenses, transport and conveyances, feeding for those not accommodated in school hostels, sundry expenses incurred during the entire duration of their undergraduate medical education and training were carefully recorded, refined and used in developing the standard template of the direct personal educational expenses. This aspect of the research activity involved data gathering through field study and administration of direct contact interactions (interviews) afforded the author the opportunity to obtain vital information on personal expenses during medical studies, used to compile the template on direct private educational cost and for construction of total cost. These procedures were followed to enable us obtain reliable total expenditure incurred in training of physicians in Nigeria, estimate lifecycle career earnings, in performing cost benefit analysis and determining the rate of return to medical education in Nigeria.

Since the expenditure profile of individual participant's medical education and residency training varied, depending on location, institution and region; the paper obtained sample representation another 18 consultants with three each from the residency training centre drawn from six geo-political zones. Respondents were purposively selected and relevant data collected through direct contact personal interviews or email administered survey instruments. These respondents were given assurances that their identities will be protected and treated with utmost confidentially. Thus details of participants' personal data are disclosed in this research report. Additionally, data on direct and indirect institutional expenditures were extracted from the brochure and other published information of the surveyed public medical schools and government agencies. These data and information are available in the official web-sites of Nigerian governments and public universities.

Secondary data were sourced from the published reports of the sampled public medical schools in Nigeria, the Federal Ministry of Health (FMOH), Medical and Dental Council of Nigeria (MDCN), National Postgraduate College of Medicine, National Bureau of Statistics (NBS), WHO and United Nations organization. These secondary data pertain to cost of training for undergraduate programme expenses such as hostel accommodation, feeding, direct levy for laboratory and research material usage (direct personal expenses) payment in medicals were extracted from the official records of the surveyed medical schools. These were extracted from the published reports the relevant universities and the medical schools. Stipends payments to the graduate physicians during the internship programme were also obtained from the Bursary department of the relevant institutions. The surveyed medical schools include: College of Medicine, University of Lagos [29]; College of Medicine, University of Benin [30]; College of Medicine, Nnamdi Azikiwe University, Nnewi [31]; College of Medicine, 
Obafemi Awolowo University, Ile-Ife [32]; College of Medicine, University of Nigeria Nsukka and College of Medicine, University of Jos [33]. Other sources of secondary data were: Medical and Dental Council of Nigeria, National Postgraduate Medical College, National Bureau of Statistics (NBS). Physicians' salary structure was duly verified from the 2009 Consolidated Medical Salary Scale (CONMESS) gazette [34] (FGN, 2009) which regulate salaries of doctors in government-owned hospitals and public service.

Baseline mean values of primary data generated through survey and mean secondary data of individual medical education expenditures from institutional sources were triangulated in establishing absolute mean value of expenditure items. Thus, mean of means of these two variants of education expenses were used in construction of absolute unit investments. Similarly, commencement salaries for newly qualified general physicians and consultant-doctors were based from Federal Government of Nigeria's consolidated medical salary scheme (CONMESS) [34] were used in deriving baseline data-sets and mean values of data used in simulation of the consultant and GP physicians' 35 years lifecycle earnings.

\subsection{Cost Construction, Earnings Estimation and Spending Efficiency}

\subsubsection{Construction of Physicians' Medical Education Expenditures}

Cost construction involves compilation of the various species of expenditures incurred by individuals together with institutional expenditures on acquisition of medical certification. Cost elements that make-up investments in medical training this research have been restricted to the expenses incurred exclusively for undergraduate education and post-registration residency programme in medicine. Other variables captured in the models of this study are the physicians' career earnings, age, duration of service, personal income taxes accruing to the state. Cost constitutes a core variable used in assessing feasibility and economic viability of investment in medical education. Cost of medical education can be classified broadly into private and public spends. Private and public costs in education incurred either by direct monetary expense, imputed costs, government bursary and institutional expenditures [11]. Social costs arise from negative spill-over effect of educational education [14] (Psacharoupolous, et al.). Apart from income-earnings, other socio-economic benefits are derived from investment in private person's education include crime reduction, quality leadership and good governance.

Average cost of education refers to total costs incurred by one person (per student or graduate) in the institution of learning or organization either annually or during the entire duration of specific training programme. Unit resource costing of education also known as effective cost of education refers to the unit of output of a successful learner or graduate from the individual's perspective. Costs of education comprised of individual or private costs and institutional or public costs [35]. Private costs of education are those incurred by a learner 
which are of two types; direct and indirect expenditures. Direct costs include all expenditure incurred on different items by the student, example, expenditure on tuition fees, other fees and charges, purchase of books, stationary, uniforms, hostel expenses and transport. Indirect private expenses are costs which are not directly visible and sometimes called "opportunity costs or foregone earnings represent the value of students" time or earning forgone in order to participate in a learning activity.

Medical students make use of specialized medical laboratories, clinical laboratory, clinical materials, drugs and medicaments, and research resources of the medical schools and Teaching Hospitals [4]. Thus, expenditures incurred consist of private and public costs; recurrent expenses and capital development investments. Private educational expenditures include feeding, hostel accommodation, conveyance, stationery, clothing, and consumable items. Institutional expenditures in medical education are often classified into direct and indirect expenditures as well as recurrent and capital expenditure items. Direct institutional expenses include expenditure items incurred by government-owned universities, medical schools and private institutions, in providing undergraduate, post-graduate residency programmes. Direct and indirect institutional expenditures on medical education in private universities' medical schools are largely recovered from participating students via programme charges, thus these schools charge higher fees. Direct costs of teaching and training consists of academic staff salaries, residents salaries, colleges and departments overheads, rent and accommodation costs, medical consumable costs, allocation of administrative charges [36]. Costs of teaching and training occur in college of medicine and Teaching Hospitals. Academic faculties of medical schools are engaged in patient care and, beginning from third or fourth year; thus, medical experts employed by teaching hospitals are participate involved in medical students' training.

\subsubsection{Physicians' Lifecycle Earnings Estimation}

Career earnings of graduates and or professional business incomes on another angle are the estimation of earnings from employment(s) and professional practice. Conventionally, earnings income or streams of benefits of the person(s) that acquired post-secondary education are estimated because appraisal of investments in human capital-education are usually evaluated well in advance of the project cycle, the actual span of total service years.

Labour market intelligence report of the career earnings for different cohorts of medical professionals in the Nigerian economy as presented here provides information of post-registration annual income earnings. Remuneration package of medical workforce in Nigeria's public sector, specifically the historical data of career earnings of physician in the public service is important for cost and benefit analysis and measures of returns performed in this study because greater proportion are employed by government.

From the available market intelligence information on professional income earnings of medical doctors in Nigeria, indicate that the start-up salary for med- 
ical practitioners in the federal health service earn between N195,000 - N220,000 per month [37]. This is equivalent to N2.4 million - N2.7 million per annum before personal income tax and other reductions. The entry level salary for physicians in the state service varies, depending on the pay scheme in a state. Prior to the recent new minimum wage adjustment in Nigeria, mint medical officers in federal public service are granted a minimum monthly salary of N3,500,000 or N4.2 million per annum. In government-owned hospitals, many attempts have been made to regulate salaries of doctors is the Consolidated Medical Salary Scale (CONMESS) [34]. Physicians could earn higher if they specialize and become consultants in the medical line; specialists, including obstetricians, cardiologists, gynecologists, dentists and surgeons were the highest earners. According to the reports, consultant physicians working in reputable hospitals in Nigeria earn about N750,000 and above per month. There are disparities in the remuneration packages of physicians in federal hospitals compared to some state-owned hospitals. Obviously, doctors in private hospitals may not earn the same as those in public hospitals. Physicians' earnings increase considerably with time, experience and specialty; whilst the medical practitioners that enjoy the highest patronage, salaries or professional fees are the senior doctors, consultants and specialists.

\subsection{Human Capital Measurement Models and Methodology Development}

Human capital investment theory, signalling (earnings premium) theory alongside resource allocation efficiency in education are eclectics' of theoretical foundation on which the cost benefit analysis, break-even point, incremental rate of returns and profitability indexing in this paper are erected [10]. Patrinos and Psacharopolous [20] identified the "elaborate" or full cost and earnings discounting cash-flows method and Mincer's "earnings" methods developed by Mincer [16] as appropriate and reliable approaches to appraise investment to education and measuring of returns. For instance, Mincer's earnings regression method does not incorporate total costs of education (direct and indirect costs of education) which is the main weakness of the earnings approach; hence, it is not used in this study. Flowing from the salient defects and inconsistency frequently encountered by human capital evaluator, the elaborate method is preferred and adoption in this study.

The internal rate of return of the "elaborate method" takes into account age-income profiles in its framework in earnings estimation [14]. The IRR models utilise individual level data to estimate the internal rates of return at which the sum of present values of expected lifetime incomes and foregone earnings and direct expenses of higher education are equated. These two methods are complementary, but the regression analysis is generally favoured in macroeconomics for providing estimates of private market returns to each additional year of "schooling" at various educational levels. It is also favoured for allowing formal stability tests of returns to educational degrees over time, especially the ad- 
ditional return to each additional year of schooling. Unfortunately, Mincer's earnings regression analysis had not produced reliable private rate(s) of economic returns to investments in education [10].

Time value of money theorem necessitates that streams of cash flows are discounted at specific rates to net present value equates internal rate of return (IRR) at a point where the values becomes zero. Internal rate of return is used in evaluation of viability of investments or projects. The "elaborate discounted cash-flows" with "internal rate of return" methodology, has the advantage of incorporating direct and public costs of education and lifecycle earnings in its measurement of returns to education. IRR method estimates are expected to result in lower rates of return than the regression method, when foregone earnings are significant. Thus, the break-even period analysis is employed calculation of earliest recovery period and the IRR is applied in measuring the private rates of returns and marginal rate of returns to medical education. Present values of net cash-flows is used in deriving profitability index of medical education

\subsubsection{Commercial Investment Efficiency Measurement Methods}

Different appraisal techniques are conventionally applied in assessment of commercial investment efficiency in literature in conducting pre-implementation and post-mortem assessment of the feasibility of investments in medical education,

Break-even period in the context of project evaluation refers to the period of time required to recoup funds expended in an investment. Thus, breakeven or payback period measures the earliest expected time horizon streams of cash inflow generated by an investment would fully recoup its outflows [38]. Time value of money (TVM) is not always taken into consideration in a break-even period. The equation functions of break-even period outflows and earnings inflows of an investment can be expressed as follows:

$$
\text { Bep }=\sum_{i=1}^{n}=\left[\frac{B t-C t}{(1+r)^{t}}>\frac{B t_{n}-C t}{\left(1+r_{d}\right)^{t}}\right] \Rightarrow>0
$$

\section{Net present value with internal rate of return (IRR) method}

Net Present Value method of evaluating investments in medical education involves discounting of total upfront educational expenditures with additional capitalizable expenses and lifecycle career earnings of physicians to derive net present value of the intellectual capital asset. The net present value (NPV) method is a metric used in capital budgeting to analyze the profitability of a projected investment or project asset. NPV utilizes 'time value of money (TVM) theorem to convert the different fund outflows and outflows to a common net present value. These species of investment appraisal methods amplifies private-commercial expenditure efficiency and public spending efficiency of medical educational investments [10].

Internal rate of return (IRR) is a metric used in project evaluation to estimate viability of potential investments [4] [14]. Internal rate of return that yields effective discount rate of the net present value (NPV) of cash flows from a partic- 
ular project equal to zero; NPV minus IRR is equal to zero. Financial mathematical model adopted for calculating of net present value of net cash-flows on gross earnings from investment or medical education is written as:

$$
N P V=I R R=\sum_{i=1} n=\frac{[B i(1-a o)(1-d T i)}{(1+I R R)^{t}} \frac{-P C i]}{L} L o i=0
$$

\section{Marginal rate of returns on wage difference of general physicians and specialists}

The signalling method for earnings differential in labour wages analysis framework measures the marginal rate of returns between higher and lower levels of education which in our context, focuses on MBBS doctors and MBBS + FNCP specialist physicians. The empirical models and structure of equation functions appropriately applied in analyzing earnings differentials or premium between MBBS holders and MBBS + FNCP physicians is borrowed from Psacharoupolous methodology [14] and used in ascertaining additional costs and earnings, marginal cost and benefits. The equation function for marginal rate of return method is specified as:

$$
\begin{aligned}
\log _{100}\left(\text { inc }_{\mathrm{it}-1}\right)= & \{\beta 0+\beta 1-+\beta 1+\beta 2 \mathrm{FNCP} \\
& +\beta 3 \operatorname{Expr}_{\mathrm{it}-1}+\beta 4 \operatorname{Expr}_{\mathrm{it}-1}^{2}+\mathrm{Eu}_{\mathrm{it}-1}
\end{aligned}
$$

where: (a) $B=$ Career earnings; $\beta 0$ is constant term; $\beta 1$ is earnings variables whilst $C$ represents cost and $\beta 0$ is constant with $\beta 1$ is cost variables in the benefits-costs analysis equation function of the average general physicians MBBS graduate medical education of the individual doctors and post-registration earnings in relevant level.

Profitability index: Profitability Index or ratio expresses the relationship between present values of net cash flow of an investment or project asset numerator to total upfront investment outlay. The present value of intellectual capital asset of individual physicians (MBBS certified and Consultant-physicians) represents net residue of the aggregate simulated lifecycle earnings after deducting total upfront medical education expenditures in [4] [38] Odufalu \& Lotto, (2003). Profitability index functions are expressed in as follows:

$$
P I=\left[\frac{B t-C t}{(1+r)^{t}} / \frac{B t_{n}-C t}{\left(1+r_{d}\right)^{t}}\right]=>0,1,2, n
$$

The paper conclude that break-even period which determines number of years it takes streams of cash inflow of investments to fully recoup its outflows [38] gives investors idea of minimum time such capital can be available for reinvestment. This measure of private expenditure efficiency enhances career selection and investing decision because it guides investors to understand tentative time horizon of recouping capital investment. Internal rate of return provides effective discount rate that yields net present value (NPV) of all the streams of cash flows from project assets is equal to zero. NPV minus IRR becomes zero.

Returns to education investments is measured in terms of income obtained as a result of education rate of return by estimating costs of investment expected 
higher financial returns. Apparently, normal, above-normal or below-normal profits have implication for viability for private expenditure in medical education and public policy with respect to public expenditures on medical/higher education generally. When rate of returns to medical education is normal, indicates that there is equilibrium in supply and demand in labour market. Abnormal high rate of return to medical education signifies shortage in supply of physicians and exorbitant wage rates. Similarly, surplus supply of doctors in an economy is often characterized by a rate of return below that of a person with a similar investment. In competitive market, high relative rate of return in the short run would be characterized by an increase in the number of individuals choosing a medical profession, and hence would lead to normal rates of return.

\subsubsection{Model Variables and Specifications}

Relevant components of individual's medical education expenditures comprising total individual direct and indirect) expenditures and institutional expenditure (recurrent and capital expenditures absorption) represent the dependent covariates. The simulated physicians' 35 lifecycle years' average total earnings is the independent covariates in the models. The number of years derived from break-even period, private rate of returns derived from IRR - NPV, marginal rates of return on earnings premium of consultants and profitability ratios represent parametric test statistics to measure commercial spending efficiency.

Definition of the variables to be used in the study is presented in Table 1 below.

\subsubsection{Models Specifications and Development}

\section{1) Break-even period model}

Break-even analysis of out-flows and inflows from earnings is computed using the traditional cost outlay and estimated fund inflows without cost of funds and personal income on gross earnings [4] [14].

Research Question (RQ. 1): To what extend can the physician's career earnings replenish upfront investments within the period taken to get certified/licensed doctors medical education?

The sets of system equation functions of this model's variables commence with cost outlays on education and clinical training estimates are expressed thus:

1) Costs: $C=f\left(\beta 0+\beta 1 \cdot\right.$ Med-educ-Training $(t)^{7}+\beta 2$ NARD's Res.educ $(t)^{5+7}$

$$
+\beta \text { dummy }+\delta \cdot X+u)
$$

Physicians' life-cycle career income earnings estimates in 35 years can be expressed as:

2) $\mathrm{B}($ Career Earnings $=1 \mid \mathrm{x})=\Phi\left(\beta 0+\beta 1_{\mathrm{MBBS}}\right.$ earnings in $(\mathrm{t}) 7^{, \mathrm{n}}+\beta 2_{\mathrm{MBBS}+\mathrm{FNCP}}$ earnings (t) $5^{+7}, \mathrm{n}+\beta 3_{\mathrm{EMPCh}}$ aracteristics $+\delta+\mathrm{X}+\mathrm{u}$ )

Combining cost estimates equations together with career income-earnings equation, from Equation (3.5.1a) and the second equation in (3.5.2b) results in following equations: 
Table 1. Variable description and definitions.

\begin{tabular}{|c|c|c|}
\hline \multicolumn{2}{|c|}{ Acronym Variable Description } & Definition \\
\hline \multicolumn{3}{|c|}{ Species of Commercial Expenditure Efficiency Measure Employed } \\
\hline $\operatorname{Bepb}_{(1)}$ & Break-even Period & Break-even Period (BEP) is number of years of full recovery \\
\hline $\operatorname{Pror}_{(2)}$ & Rate of Returns & $\begin{array}{l}\text { Rate of Returns (ROR) is as the private rate of return on investments on medical education of a } \\
\text { physician based on lifecycle gross earnings. }\end{array}$ \\
\hline $\operatorname{Mirr}_{(4)}$ & Marginal Rate of Returns & $\begin{array}{l}\text { Marginal Rate of Returns }\left(\mathrm{MRR}_{4}\right) \text { is the rate of return relating to wage difference (earnings } \\
\text { premium) between remuneration of consultant physician above general practice physician } \\
\text { (ignoring tax and cost of capital) }\end{array}$ \\
\hline $\operatorname{Prnd}_{(4)}$ & Profitability Index & $\begin{array}{l}\text { Profitability index is the ratio of present value of net cash flow to individual's total upfront } \\
\text { investment }\end{array}$ \\
\hline \multicolumn{3}{|c|}{ Model Variables in Human Capital Measurement Models } \\
\hline $\operatorname{Prnv}_{(1)}$ & $\begin{array}{l}\text { Private (Individual's) Investments in } \\
\text { Medical Education }\end{array}$ & $\begin{array}{l}\text { Private or unit upfront investment expenditure is the total educational expenditure which } \\
\text { individual participant incurred on medical education incurred to acquire MB.BS degree and } \\
\text { license to practice medicine }\end{array}$ \\
\hline $\operatorname{Pcrg}_{(1)}$ & $\begin{array}{l}\text { Public (Institutional) Subvention } \\
\text { Expenditure in Medical Education }\end{array}$ & $\begin{array}{l}\text { Physician's lifecycle career earnings is the total earnings of an average Nigerian physician } \\
\text { employed in the public health service for } 35 \text { years at retirement of } 60 \text { years of age. }\end{array}$ \\
\hline $\operatorname{Prnv}_{(2)}$ & $\begin{array}{l}\text { Individual Participant's Investments } \\
\text { in residency training }\end{array}$ & $\begin{array}{l}\text { Individual's additional upfront investment expenditure is the additional total educational } \\
\text { expenditure which individual participant in medical education incurred in a } 6 \text {-year residency } \\
\text { training in acquiring fellowship certification. }\end{array}$ \\
\hline $\operatorname{Punv}_{(2)}$ & $\begin{array}{l}\text { Public Additional Subvention } \\
\text { Expenditure on Residency Training }\end{array}$ & $\begin{array}{l}\text { Public additional upfront investment expenditure is additional total educational expenditure } \\
\text { incurred by public entity during the 6-year Residency training of Consultants }\end{array}$ \\
\hline $\operatorname{Crng}_{(2)}$ & $\begin{array}{l}\text { Consultant-Physician's Gross lifelong } \\
\text { Earnings }\end{array}$ & Consultant-Physician's lifecycle career earnings is the total earnings in 35 years of service \\
\hline
\end{tabular}

Source: The Authors' Compilation (2018; 2019).

$\mathrm{BEPB}=\left\{\left[\beta 0+\beta 1 \cdot \beta 1_{\mathrm{MBBS}}\right.\right.$ earnings in $\left.(t)^{7 \text { or n }}\right]\left[\right.$ or $+\beta 2_{\mathrm{MBBS} \text { FNCP }}$ earning $(t)^{5+7, \mathrm{n}}+$ $\beta 3$ dummy $)]-\left[\left(\mathrm{Co}=\left(\beta 0+\beta 1 \cdot \mathrm{MBBS} \operatorname{educ}(\mathrm{t})^{7}+\beta 2_{\mathrm{NARD}-\mathrm{R}}\right.\right.\right.$ es.educ $\left.\left.(\mathrm{t})^{5}\right)\right]=(\mathrm{Bt}-\mathrm{Co})$ $=0$.

The equation function applied in deriving the Net Present Value(s) of human capital investment asset of the average Nigerian physician that practice in the economy is given as follows:

$$
\mathrm{BEPB}=\sum_{i=1}^{n}=\left\{\frac{B\{\text { earnings })}{(1+r)^{t}} \&+U\right\}-\left\{\frac{C\{\cos t)}{\left(1+r_{d}\right)^{t n n}} \&+u .=0 .\right.
$$

The model functions duly specified above (3.5.1a, 3.5.1b, 3.5.1c) may be rearranged as:

$$
\begin{gathered}
\mathrm{BEPB}=\sum 7,{ }^{, 5, \mathrm{n}} /_{\mathrm{t}-\mathrm{I}} \mathrm{Bi}-\mathrm{Ci} /(1+\mathrm{r})^{\mathrm{n}=35}=0 \\
\mathrm{BEPB}=\sum_{i=1}^{n}=\left\{\frac{B\left\{\text { earnings }^{2}\right.}{(1+r)^{t}} \&+U\right\}-\left\{\frac{C\{\cos t)}{\left(1+r_{d}\right)^{t n n}} \&+u .=0 .\right.
\end{gathered}
$$

Hypothesis test formulated for break-even period $\mathrm{Ho}_{1}$ is: Physician's career earnings cannot replenish total educational expenditure outlay in medical education within a period equal to the duration of training. 


\section{2) Net present value (NPV) - Internal rate (IRR) model}

This model establishes private rate of returns in general education (MBBS degree).

Research Question (RQ. 2): To what extent does the rate of return on investments to medical education satisfy 18 percent as the minimum rate of return acceptance criterion on risk-free on government securities?

This model is stated as follows:

Net Cash flow-Y $=\mathrm{a}+\mathrm{b}\left[\left(\mathrm{B}\right.\right.$ Gp-earnings $\left.\mathrm{t}_{35}\right)-\left(\mathrm{C}_{(1=7)}\right.$ (pr-inv) $\mathrm{r}$

The estimated lifecycle earnings $(\mathrm{Y})$ are predicted for each education level, and these predicted returns are used in solving equation (3.5.2b) in deriving private rates of return to medical education $(r)$. The $r$, represented by the internal rate of return (IRR) is specified as:

$$
\begin{aligned}
\text { PROR } & =\mathrm{S}+1 \sum \mathrm{n}[f(B \mathrm{Gp} \text { - earning } \\
& \left.\left.=\text { Not=35 })-\mathrm{C}_{(\mathrm{t}=7)}\left(\operatorname{Prnv}_{(1)}\right) / 1+(\mathrm{x}) \mathrm{r}\right)\right] \\
& =\text { interest }[\mathrm{r}]
\end{aligned}
$$

where: $\mathrm{B}_{\mathrm{t}=35 \text { (Gpractice-earinga) }}$ represent total career earnings of an individual physician in a-35 lifecycle years of service and $\mathrm{C}_{\mathrm{t}=7}$ (upfront investment outlays before deduction of personal income taxes from the physicians' earning of medical practice.

$\mathrm{Ho}_{2}$ : Rate of private return (based on gross earnings) on investment to medical education in Nigeria is not significantly lower than 15 percent interest rates for Nigerian treasury bills as a minimum criterion for adoption of medical education.

\section{3) Marginal rate of return on residency training model}

This model determines marginal rate of return associated with additional investment from higher wage price (earnings premium) of consultants that graduated from residency programme. We simulated consultant physician gross earnings for 35 years in computation of marginal IRR rate of return.

Research Question (RQ.3): To what extent does individual's marginal private rate returns on additional capital investments justify such additional resources expenditure in the residency medical training programme of consultant- physicians?

Equation functions of this model are stated as:

MARR $=\mathrm{S}+1 \sum \mathrm{n}\left[\mathrm{f}\left(\mathrm{BCp}-\right.\right.$ earning $\left._{\mathrm{i}=35}\right)-\left[\mathrm{C}_{(\mathrm{t}=7)+}(\mathrm{xtra}-\right.$ Resinv $\left.\left.) / 1+(\mathrm{x}) \mathrm{r}\right)\right]=$ No Int. [r] (3.4.3) $\mathrm{Ho}_{3}$ : The marginal rate of returns to the additional investment expenditure for residency programme in Nigeria is not significantly lower than 12 percent above the rate of returns to those of the MBBS certified general practice physicians.

\section{4) Profitability index model}

Profitability index in this model expresses ratio of net present value of earnings on total investment and a measure of aggregate surplus of net inflows on cost outlays [38].

Research Question (RQ. 4): To what extent does profitability index of general medical education and residency training in Nigeria equate to comparable aver- 
age profitability index of medical education in range of ratio of 1.2: 1.0 of other economies; for example, USA?

The equation functions in this model can be expressed as flows:

$$
P-I N D=\left[\frac{B t-C t}{(1+r)^{t}} / \frac{B t_{n}-C t}{\left(1+r_{d}\right)^{t}}\right]=>0,1,2, n
$$

$\mathrm{Ho}_{4}$ : Profitability index (ratio) of present value of net cash flow of medical education in Nigeria is not significantly lower than a ratio of 1.20 or at least one-to-one point basis.

\subsection{Data Estimation and Evaluation Procedure}

The relevant data-sets, upfront costs, earnings, net cash-flows, present values of cash-flows without cost of capital and interest charges for cost of funds were subjected to the standard econometric procedures; notably, unit root, stationarity and co-integration screening in test-check their suitability in the models [39] [40]. The decision criterion for testing results are; if the computed BEPB, PROR, MARR and P-IND that falls below the specified as seven or 14 years; $18 \% ; 15 \%$ of cut-off acceptance criterion, subject to 5\% significance level; we accept Ho and reject $\mathrm{Ha}$; but otherwise, accept $\mathrm{Ha}$ and reject $\mathrm{HO}$.

These assumptions were made in model development, data configuration and analyses:

1) Total cost of outlay for basic medicine is 6 years plus one-year internship for clinical practice as a precondition for obtaining license. It must be emphasised that the constructed of investment in medical education excludes pre-tertiary education costs - those educational costs on primary and secondary schooling because Nigerian government provides free and compulsory education for these stages. Second, non-medical degree holders and licensed physicians are barred from the practice of medicine.

2) Stipend received by physicians during internship and National youth service years were considered as career earnings because the Youth Service is compulsory in law and necessary condition for employment in Nigeria for Nigerians. Clinical internship is pre-condition for gaining license to practice [41].

3) Average age of students at entry is between $17 / 18$; and 25 at graduation

4) Retirement age in Nigeria is 60 with a maximum of 35 years of active service and 70 years for consultants.

5) Annual increment rate of $5 \%$ was applied from second year of employment up to year 24 and $2.5 \%$ from year 25 to 35 ; after that no more annual increment is to be granted.

\section{Data Analysis and Results}

Results of data screening, evaluation and tested hypotheses is presented in four capsules, beginning with break-even period analysis, measures of returns and profitability index. 


\subsection{Data Evaluation Results (Unit Root and Co-Integration Tests)}

\subsubsection{Results of Unit Root}

Augmented Dickey-Fuller (ADF) statistics were obtained for time series and results as presented in Table 2, show that the series were integrated of order zero $1(0)$.

\subsubsection{Co-Integration Results}

Co-integration test were undertaken to assess behaviour of variables in the models in long run and short run and where two or more non stationary time series exhibit some degree of instability in time series when a linear combination of them is formed [39] [40]. Results of the screening test performances of the model variables are segregated and presented Table 3 for the rank test statistics and maximum Eigen value in Table 4 respectively.

Screening results from trace and maximum Eigen statistics respectively (Table 3 and Table 4) indicate that the co-integrating equations fitted well between the regressand and the regressors at $5 \%$ level in the model [39].

Table 2. Augmented dickey fuller-unit root statistics (earnings and costs).

\begin{tabular}{|c|c|c|c|c|c|}
\hline Model Variables & $\begin{array}{l}\text { Lag of } \\
\text { ADF }\end{array}$ & $\begin{array}{c}\text { ADF test } \\
\text { statistics@Levels }\end{array}$ & $\begin{array}{l}\text { ADF statistics } \\
@ 1^{\text {st }} \text { difference }\end{array}$ & $\begin{array}{c}\text { Order of } \\
\text { integration }\end{array}$ & Remark \\
\hline Upfront Costs $_{(\mathrm{A})}$ & 1 & -3.352360 & -1.964183 & $\mathrm{I}(0)$ & Stationary \\
\hline Upfront Costs $_{(\mathrm{B})}$ & 1 & -3.352360 & -1.964183 & $\mathrm{I}(0)$ & Stationary \\
\hline Bepb Cash Flow & 1 & -1.488462 & -3.685309 & $\mathrm{I}(1)$ & Stationary \\
\hline Bepb Cash Flow ${ }_{B}$ & 1 & -1.491746 & -3.764309 & $\mathrm{I}(1)$ & Stationary \\
\hline Earnings $_{(\mathrm{A})} @ \mathrm{PV}$ & 0 & -1.476422 & -3.684309 & $\mathrm{I}(1)$ & Stationary \\
\hline Earnings $_{(\mathrm{B})} @ \mathrm{PV}$ & 0 & -1.134556 & -3.687307 & $\mathrm{I}(1)$ & Stationary \\
\hline Net Cash-flow $\mathrm{PV}_{\mathrm{A}}$ & 1 & -0.891756 & -4.687352 & $\mathrm{I}(1)$ & Stationary \\
\hline Net Cash-flow $\mathrm{PV}_{\mathrm{B}}$ & & -0.976456 & -4.768307 & $\mathrm{I}(1)$ & Stationary \\
\hline
\end{tabular}

5\% critical level (-3.622033) Source: Author’s computation using E-views 9.0.

Table 3. Unrestricted Co-integration Rank Test Results (Trace).

\begin{tabular}{|c|c|c|c|c|}
\hline \multicolumn{4}{|c|}{ Unrestricted Co-integration Rank Test (Trace) } & \multirow{3}{*}{ Prob. ${ }^{* *}$} \\
\hline Hypothesized & Eigen value & Trace & 0.05 & \\
\hline No. of CE(s) & Statistic & Statistic & Critical Value & \\
\hline None ${ }^{*}$ & 0.319536 & 19.08896 & 21.23443 & 0.03254 \\
\hline At most 1 & 0.004112 & 0.019772 & 3.64344 & 0.3993 \\
\hline At most 2 & 0.001472 & 0.015866 & 3.84462 & 0.6730 \\
\hline At most 3 & 0.000172 & 0.005866 & 3.94046 & 0.7429 \\
\hline At most 4 & 0.003892 & 0.017657 & 3.59646 & 0.3899 \\
\hline
\end{tabular}

Trace test indicates 3 co-integrating eqn(s) at the 0.05 level; ${ }^{*}$ denotes rejection of the hypothesis at the 0.05 level; ${ }^{* *}$ MacKinnon-Haug-Michelis (1999) p-values Source: Author's computation using E-views 9.0. 


\subsection{Analysis Results}

Results of data analyses and tests are rendered in Table 5.

1) Result of break-even period for full recovery of investments in general practice physicians is 5.25 and $61 / 3$ years for residency-trained consultants respectively. Payback timeframe is shorter that the seven years minimum duration of MBBS medical education is shorter than seven years duration and 6.333 full recovery periods is equally less than 50 percent (half) of 13 consecutive years spent to acquire combined MBBS plus FNCP certifications in Nigeria.

2) Individual rate of returns on investments in general medical education of average licensed general physicians is 32 percent. The returns to medical education across level exceed the prevailing the risk-free investment income accruing to government treasury bills and even the higher commercial banks' lending rates of 24 - 30 percent in the economy.

3) Marginal rate of returns to additional investment expenditures on residency training (earnings premium of consultant-physicians) is 32 percent. The incremental returns to residency training surpasses prior global or regional 12 - 15 percent rate of returns to higher education as reported in Psacharopoulous [14] and 15 percent reported in Nigeria by [42] [43]. The combined rate of returns of consultant-doctors (general medicine plus residency training) gives 64 percent on the aggregate.

Table 4. Unrestricted co-integration rank (maximum eigenvalues) results.

\begin{tabular}{ccccc}
\hline \multicolumn{2}{c}{ Unrestricted Co-integration Rank Test (Maximum Eigen Values) } & \\
\cline { 1 - 4 } $\begin{array}{c}\text { Hypothesized } \\
\text { No. of CE(s) }\end{array}$ & $\begin{array}{c}\text { Eigenvalue } \\
\text { Statistic }\end{array}$ & $\begin{array}{c}\text { Maximum Eigen } \\
\text { Statistic }\end{array}$ & $\begin{array}{c}\mathbf{0 . 0 5} \\
\text { Critical Value }\end{array}$ & \\
\hline None ${ }^{*}$ & 0.325538 & 20.129320 & 14.03742 & 0.0326 \\
At most 1 & 0.001773 & 0.005569 & 3.91286 & 0.4138 \\
At most 2 & 0.000213 & 0.004639 & 3.84462 & 0.6730 \\
At most 3 & 0.000143 & 0.004897 & 3.79466 & 0.9289 \\
At most 4 & 0.001774 & 0.005568 & 3.91286 & 0.4138 \\
\hline
\end{tabular}

Trace test indicates 3 co-integrating eqn(s) at the 0.05 level; ${ }^{\star}$ denotes rejection of the hypothesis at the 0.05 level; ${ }^{*}$ MacKinnon-Haug-Michelis (1999) p-values. Source: Author's computation using E-views 9.0.

Table 5. Comparison of calculated and idealized rate of returns.

\begin{tabular}{cccc}
\hline Models & Calc. Result & Idealized Levels & Decision Rules \\
\hline Break-Even Period $\left(\mathrm{BEPB}_{1}\right)$ & 5.25 Years & 7 Years & $\mathrm{Ho}_{1 \mathrm{a}}$ \\
Break-Even Period $\left(\mathrm{BEPB}_{2 \mathrm{res}}\right)$ & 6.33 Years & 14 Year & $\mathrm{Ho}_{1 \mathrm{~b}}$ \\
Private Rate of Returns (PROR) & $32 \%$ & $18 \%$ & $\mathrm{Ha}_{2}$ \\
Marginal Rate of Returns (MARR) & $32 \%$ & $15 \%$ & $\mathrm{Ha}_{3}$ \\
P-IND $_{(\mathrm{A})}$ & 1.32 & 1.2 & $\mathrm{Ha}_{4}$ \\
$\mathrm{P}_{\text {-IND }}$ & 1.64 & 1.2 & $\mathrm{Ha}_{4}$ \\
\hline
\end{tabular}

Source: Author's computation (2019). 
4) Net present value of cash-flows of the general physician and consultant-doctors in Nigeria worth N326 million and N744 million respectively. Profitability index derived from present value of the net cash-flows yield 1.32 and 1.69 for the Nigerian certified general physicians and consultant-physicians respectively without cost of capital and personal income taxes. The results confirm that investments in medical education across levels in Nigeria are worth-while, but more lucrative for residency training/consultant-physicians' earnings. These results are significant greater than 16 percent idealized minimum acceptance criterion for medical education while 37 percent is greater than the 12 to 15 percent bench mark as marginal rate of returns for additional investments of the consultant-physicians.

\subsection{Discussion}

Cost construction show that about N30 million and N69.5 million are committed as investments on general medical education and residency training of the average licensed general physicians and consultant-physicians respectively. The estimated lifecycle career earnings of general practice physicians and consultant-physicians employed in the public service worth N356 million and 814 million for 35 years consecutive years of service.

The break-even period for full recovery of investments in general physicians is 5.5 years which is shorter than the seven years total standard duration of MBBS programme. But it occurs around the twelfth year in medical education investment cycle. Similarly, the break-even period for recouping both the initial in general medical education and additional expenditure committed in residency training of consultant-doctor in certain sub-specialties is requires 6.25 years, which occurs around of 13 years total standard duration spent in acquiring MBBS plus FNACP certifications. Full recovery period of the consultants occurs within 50 percent of total duration of elongated duration of residency certified specialists and in the twenty-second year of the investment lifecycle. The recovery timeframe for each of these layers of medical education signifies that capital investments in medical education are recoverable in shorter timeframe which permits participants to reinvest recouped funds in other assets. The gestation periods of investments in medical education and timing of cash inflow streams confirm that medical education is a long term investments before it commencing income generation. These results signify that investments in medical education are fully recovered or recoverable in Nigerian economy and perhaps in many other climes. Plausible lesson drawn from the break-even results medical education deserve increased funding of subvention spending, probably payment of full salaries during residency and enhanced wages in order to make the career more financially rewarding and reduce debt burden.

Private rate of returns to medical education is 32 percent and 64 percent which represent direct financial gain for individual MBBS holders and consultant-physicians respectively for 35 years lifecycle career and for about 42 to 50 
years project cycle. These rates of returns obtained in this model exceed the prevailing interest rates on treasury bills and effective risk free returns of 18-to-20 percent from alternative investment options. The marginal rate of returns to additional investment expenditures on residency training (earnings premium of consultant-physicians) is 32 percent and added to 32 percent returns on the first tier medical education brings overall returns to consultant doctors to 69 percent. The marginal returns to additional investments and time resources committed in this variant of advanced professional training and research efforts leading to attainment of professorial grade in academics is highly beneficial to participants in residency programme/specialist physicians.

With profitability ratio of 1.32 percent for the MBBS holders and 1.64 percent MBBS + FNCP certified medical experts (based on 32 percent discount rate of net cash flows of the net present value) surpasses the expected investment income from government bond and treasury bills but lower than higher profitability indices of the US doctors [44]. These results provide clear indication that in investments in medical education across levels in Nigeria is worth-while.

\section{Summary, Conclusion and Recommendation}

Pre-implementation and post-investment cost-benefit analysis and assessment of viability of medical education and individual spending efficiency provide useful guide to prior participants in medical schools and currently in practice in managing their earnings prudently. It also guides prospective medical trainees in selection of course programmes and future careers.

\section{Conclusions and Policy Implications}

Academic medical education, clinical training for general medical practice and residency training of the consultant-physicians in Nigeria is capital-intensive and expensive. Physicians' medical education should be seen as private public partnership project in which the household units supply the trainees and government provides the enabling environment. Therefore, financing of medical education necessitates joint expenditure responsibility between individual participants, household units and the state. This is more-so under the present circumstance where different viruses are threatening human existence and well-being of population in many sovereigns. This paper study established that the Nigerian/MBBS certified general medical practitioner spend between seven (7) which is recoverable in 5.5 years; but full recovery of the investments occurs around the twelfth year in medical education investment cycle. Similarly, the consultant physicians with MBBS plus FNCP in Nigeria spend a total of 13 years to 16 years (in certain sub-specialties) in continuous academic education and professional training programme, but recover the total expenditures around the twenty-second year in the medical education investment project cycle in a 50 years tenor project cycle. Then, the earlier people obtain their education and training certification, the higher the benefits; in other words, there is trade-off 
between age-profile, experience and aggregate career income. The major set-back in the post graduate medical residency in Nigeria is that many of the participants or residents do not normally complete the training and obtain the desired award within the standard duration. From the results of the break-even analysis, it is apparent that medical education deserves increased funding of subvention spending, and payment of full salaries during residency and enhanced wages in order to make the career more financially rewarding and reduce debt burden [45].

The paper concludes that an investment to education and training of doctors in Nigeria is financially and economically viable. Highly educated persons/skilled professionals should endeavour to recognise their career earnings not only as core factor determining their market value (worth of lifecycle career cash-flows).

\section{Conflicts of Interest}

The authors declare no conflicts of interest regarding the publication of this paper.

\section{References}

[1] Becker, G.S. (2003) "Human Capital": A Definition. The Concise Encyclopaedia of Economics. http://www.econlib.org

[2] Investopedia (2019) Government Securities and Risk-Free Rate of Returns. Investopedia.com.

[3] Chen, J. (2016) Essentials of Technical Analysis for Financial Markets. John Wiley and Sons, New York.

[4] Roth, N. (2012) The Costs and Returns to Medical Education. University College, Berkeley.

[5] Healey, N. and Gunby, P. (2012) The Impact of Recent Government Tertiary Education Policies on Access to Higher Education. Journal of Educational Leadership, Policy and Practice, 27, 29-45.

[6] Central Bank of Nigeria (2018) Monetary Policy Circular (Nigerian Treasury Bills Interest Rates and Prime Lending Rates). Central Bank of Nigeria, Abuja.

[7] Kirigia, A., Lenity, N. and Seddoh (2006) The Cost of Health Professionals "Brain-Drain" in Kenya. BMC Health Services Research Journal, 6, Article No. 89. https://doi.org/10.1186/1472-6963-6-89

[8] Osotimehin, B.O. (2013) Nigeria National Strategic Health Development Framework (2009-2015). Federal Ministry of Health, Abuja.

[9] Organization for Economic Co-Operation and Development OECD (2001) The Well-Being of Nations: The Role of Human and Social Capital. OECD, Paris.

[10] Maani, S.A. (1999) Private and Public Returns to Investments in Secondary and Higher Education in New Zealand over Time: 1981-1996. Department of Economics, University of Auckland, Auckland.

[11] Becker, G.S. (1975) Investment in Human Capital: Effects on Earnings (Chapter 2 Online Reproduction of the Author's Original Text on Human Capital).

http://www.nber.org/books/beck.75-1 
[12] Lawanson, O.I. (2009) Human Capital Investment and Economic Development in Nigeria: The Role of Education and Health. Conference Proceedings Paper, Oxford, 24-26 June 2009.

[13] Arrow, K. (1963) Uncertainty and the Welfare Economics of Medical Care. American Economics Review, 53, 941-973.

[14] Psacharopoulos, G. (1994) Returns to Investment in Education: A Global Update. World Development, 22, 1325-1343. https://doi.org/10.1016/0305-750X(94)90007-8

[15] Fiamholtz, E.G. (1980) The Processes of Human Resource Accounting (HRA) in Managerial Accounting.

[16] Mincer, J. (1974) Schooling, Education and Earnings. Columbia University Press, New York.

[17] Mincer, J. (1997) The Production of Human Capital and the Life-Cycle of Earnings: Variations on a Theme. Journal of Labour Economics, 15, 26-47. https://doi.org/10.1086/209855

[18] Murphy, K. and Welch, F. (1989) Wage Premium for College Graduates: Recent Growth and Explanation. Educational Researcher, 18, 17-26. https://doi.org/10.3102/0013189X018004017

[19] Romele, L. and Purgailis, F. (2013) Estimation of Private and Social Rates of Returns to Investments in Education in Latvia. European Integration Studies, No. 7. https://doi.org/10.5755/j01.eis.0.7.5088

[20] Patrinos, H.A. and Psacharopoulos, G. (2004) Returns to Education in Developing Countries: A Further Update. Education Economics, 12, 1325-1343. https://doi.org/10.1080/0964529042000239140

[21] Spencer, M. (1973) Job Market Signalling. Quarterly Journal of Economics, 87, 355-374. https://doi.org/10.2307/1882010

[22] Swati, S. (2016) Does Education Determine Employment: Peculiarities of the Indian Labour Market. Studies in Business and Economics, 11, 164-180. https://doi.org/10.1515/sbe-2016-0014

[23] Olukadiya, K.S. (2016) Do You Have What It Takes to Become a Medical Doctor?

[24] Engelage, S. and Hadjar, A. (2008) Promotion and Karrierre. Schweizerissche Zeifchrift fur Soziologie, 34, 71-93.

[25] Mertens, A., Röbken, H. and Mertens, A. (2013) Does a Doctoral Degree Pay Off? An Empirical Analysis of Rates of Return of German Doctorate Holders. Higher Education, 66, 217-231. https://doi.org/10.1007/s10734-012-9600-x

[26] Borad, N. (2015) The Value Medical Education in the United States. B.A. Economics Thesis, The College of New Jersey, Ewing Township.

[27] van der Steerg, M., van der Wiel, K. and Wouterse, B. (2014) Individual Returns to a PhD Education in the Netherlands: Income Differences between Masters and PhDs.

[28] Chisholm-Burns, M.A., Gatwood, J. and Spivey, C.A. (2016) Economic Analysis of Obtaining a PharmD Degree and Career as a Pharmacist. Americal Journal of Pharmaceutical Education, 79, 117. https://doi.org/10.5688/ajpe798117

[29] University of Lagos: Brochure and Programmes Fees (Various). https://unilag.edu.ng/

[30] University of Benin. Brochure and Programmes Fees (Various). http://www.uniben.edu.org/

[31] Nnamdi Azikiwe University (UniZik), Awka. Brochure and Programmes Fees 
(Various). http://www.unizik.edu.ng/

[32] Obafemi Awolowo University, Ile-Ife: Brochure and Programmes Fees (Various). http://www.oauife.edu.ng/

[33] University of Jos: Brochure and Programmes Fees (Various). https://www.unijos.edu.ng/

[34] Federal Government of Nigeria (FGN) (2009) Consolidated Medical Salary Scale-CONMESS in 2009 (FGN, 2009). National Incomes and Wages Commission, Abuja

[35] Shultz, T.W. (1972) Optimal Investment in College Instructions: Equity and Efficiency. Journal of Political Economy, 80, S2-S30. https://doi.org/10.1086/259983

[36] Gammon, E. and Franzini, L. (2011) Revisiting the Cost of Medical Student Education: A Measure of Experience of the University of Texas-Houston Medical School, Texas.

[37] Abbey, L. (2015) How Much Do Nigerian Doctors Earn? Nigeria’s Bulletin, Discussion in Jobs and Careers, Online Publication: August 12, 2015.

[38] Odufalu, O. and Lotto, M.A. (2003) Project Analysis and Evaluation: Principles and Techniques. Concept Publications, Lagos.

[39] Johansen, S. and Juselius, K. (1990) Maximum Likelihood Estimation and Inference on Co-Integration with Application to Demand of Money. Oxford Bulletin of Economics and Statistics, 52, 169-210. https://doi.org/10.1111/j.1468-0084.1990.mp52002003.x

[40] Gujarati, D.N. and Sengaetha (2008) Basic Economics. 4th Edition, McGraw-Hill, Singapore.

[41] Medical and Dental Practitioners Act, 2004, Laws of Federal Republic of Nigeria of Nigeria.

[42] Okuwa, O.B. (2004) Private Returns to Higher Education in Nigeria. AERC Research Paper 139, African Economic Research Consortium, Nairobi (March, 2004).

[43] Wei, H. (2010) Measuring Economic Returns to Post-School Education in Australia. Research Paper 1351.0.55.032; Economic Analysis and Reporting Branch, Australian Bureau of Statistics, Canberra.

[44] Leigh, J.P., Tancredi, D., Jeranti, A. and Kravitz, R.L. (2010) Physician Wages across Specialties: Informing the Physician Reimbursement Debate. Archives of Internal Medicine, 170, 1728-1734. https://doi.org/10.1001/archinternmed.2010.350

[45] Ehrenberg, R.G. and Smith, R.S. (1996) Modern Labor Economics: Theory and Public Policy. Prentice Hall, Upper Saddle River. 